\title{
THE RULE AGAINST GIVIL ACTIONS FOR PERJURY IN ADMINISTRATIVE AGENCY PROCEEDINGS: A HOBGOBLIN OF LITTLE MINDS
}

\author{
"Thou shalt not bear false witness against thy neighbour."1
}

\section{INTRODUCTION}

For four hundred years a general rule of law has been that a person injured as a result of another person's perjury in a judicial proceeding may not maintain a civil action for damages against the perjurer. ${ }^{2}$ In a recent case the Second Circuit extended this rule by denying relief to a plaintiff allegedly injured by misrepresentations and perjured testimony presented to an administrative agency conducting an investigation. $^{3}$ The rule against civil actions for perjury, however, is grounded principally in the doctrines of res judicata and collateral estoppel. Those doctrines in most instances do not apply to issues decided by an administrative agency after a hearing or an investigation because the parties to such proceedings generally do not have the procedural safeguards, such as the opportunity for discovery and cross-examination, available in judicial proceedings. Accordingly, the rule against civil actions for perjury should not apply in the administrative context.

Part I of this Comment discusses the background and origins of the rule against civil actions for perjury. Part II examines the Second Circuit's application of the rule to an administrative agency investigation. Part III concludes that for the same reasons courts have not gener-

1 Exodus 20:16 (God).

2 The earliest application of the rule is found in Damport v. Sympson, 78 Eng. Rep. 769 (K.B. 1596). For a detailed discussion of the rule, see Note, Civil Remedies for Perjury: A Proposal for a Tort Action, 19 ARIz. L. REv. 349 (1977).

"Perjury" is used in this Comment to mean a witness's deliberately false swearing to a material matter in an official adminstrative or judicial proceeding. Perjury has always been considered one of the most serious crimes. Under Roman law and French law the punishment for bearing false witness was death. See Gershman, The "Perjury Trap", 129 U. PA. L. Rev. 624, 636 (1981); see also S. BoK, LyIng: MORAL Choices in Public and Private Life 160 (1978). False testimony undermines the proper and effective administration of justice; it may cost an individual his life, liberty, or property. See Gershman, supra, at 636.

Alberta Gas Chems., Ltd. v. Celanese Corp., 497 F. Supp. 637 (S.D.N.Y. 1980), rev'd, 650 F.2d 9 (2d Cir.), on remand, 529 F. Supp. 226 (S.D.N.Y. 1981), affd mein., 697 F.2d 287 (2d Cir.) (unpublished decision), cert. denied, 103 S. Ct. 580 (1982).

The final disposition of the case by the Second Circuit was an unpublished decision. See infra note 56. 
ally extended the doctrines of res judicata and collateral estoppel to administrative proceedings, they should not apply the rule against civil actions for perjury to perjury committed during such proceedings.

\section{The Rule Against Givil Actions for Perjury as Res Judicata}

"No action lies to recover damages caused by perjury." If $A$ is injured by the false or misleading testimony of $B$ in a judicial proceeding, $A$ cannot maintain an action for damages against $B ; ;^{\mathbf{5}} A$ can obtain relief only by a direct attack on the judgment. ${ }^{B}$ So it was at common law, and although some observers have called for its abandonment, ${ }^{7}$ courts today are unanimous in following that ancient rule. ${ }^{8}$

40 C.J.S. Perjury § 92 (1951 \& 1983 Supp.).

- See, e.g., Smith v. Sinclair, 424 F. Supp. 1108, 1113 (W.D. Okla. 1976) ("It is fundamental that in the absence of statute an unsuccessful litigant may not maintain a civil suit for damages against a person for alleged perjury committed by him in a civil action, a criminal prosecution or other proceeding, either as a party or as a witness.") (citations omitted).

- The principal available remedy is to vacate the judgment; recovery, when available, is limited to restitution rather than damages. See Note, supra note 2, at 352-62.

Rule 60(b) of the Federal Rules of Civil Procedure relaxes the restrictions imposed at common law on vacating a judgment:

Mistakes; Inadvertence; Excusable Neglect; Newly Discovered Evidence; Fraud, etc. On motion and upon such terms as are just, the court may relieve a party or his legal representative from a final judgment, order, or proceeding for the following reasons: (1) mistake, inadvertence, surprise or excusable neglect; (2) newly discovered evidence which by due diligence could not have been discovered in time to move for a new trial under Rule 59(b); (3) fraud (whether heretofore denominated intrinsic or extrinsic), misrepresentation, or other misconduct of an adverse party; (4) the judgment is void; (5) the judgment has been satisfied, released, or discharged, or a prior judgment upon which it is based has been reversed or otherwise vacated, or it is no longer equitable that the judgment should have prospective application; or (6) any other reason justifying relief from the operation of the judgment .... Writs of coram nobis, coram vobis, audita querela, and bills of review and bills in the nature of a bill of review, are abolished, and the procedure for obtaining any relief from a judgment shall be by motion as prescribed in these rules or by an independent action.

Perjury may be brought within that rule. See Estate of Murdoch v. Philadelphia, 432 F.2d 867, 870 (3d Cir. 1970) (false affidavit ground for relief under rule 60(b)(3)); see also 11 C. Wright \& A. Miller, Federal Practice \& Procedure § 2861, at 196 (1973); Note, supra note 2, at 359.

7 E.g., Note, supra note 2, at 351.

8 Newin Corp. v. Hartford Accident \& Indemnity Co., 37 N.Y.2d 211, 217, 333 N.E.2d 163, 166, 371 N.Y.S.2d 884, 889 (1975). See, e.g., Charles v. Wade, 665 F.2d 661, 666 (5th Cir. 1982), cert. denied, 103 S. Ct. 1426 (1983); Droppleman v. Horsley, 372 F.2d 249, 251 (10th Cir. 1967); Chase v. Brecke, 509 F. Supp. 241, 242-43 (D. Minn. 1981); Smith v. Sinclair, 424 F. Supp. 1108, 1113 (W.D. Okla. 1976); MerrittChapman \& Scott Corp. v. Elgin Coal, Inc., 358 F. Supp. 17, 22 (E.D. Tenn. 1972), 
There are several well-established reasons for the rule against civil actions for perjury. First, the rule encourages witnesses to speak freely in court $^{\boldsymbol{9}}$ by protecting them from subsequently being sued for perjury. ${ }^{10}$ Under this view, the threat of frivolous perjury suits and attempts at intimidating witnesses outweigh the usefulness of private litigants enforcing the laws against perjury. ${ }^{11}$

Second, the rule is believed necessary for the finality of judg-

affd mein., 477 F.2d 598 (6th Cir. 1973); Kachig v. Boothe, 22 Cal. App. 3d 626, 637, 99 Cal. Rptr. 393, 399 (1971); Hokanson v. Lichtor, 5 Kan. App. 2d 802, 626 P.2d 214, 222 (1981); Alexander v. City of Peekskill, 80 A.D.2d 626, 626-27, 436 N.Y.S.2d 327, 328-29 (1981); Serrano v. Flight Motel, Inc., 95 Misc. 2d 669, 672, 408 N.Y.S.2d 198, 200 (1978); W.G. Platts, Inc. v. Platts, 73 Wash. 2d 434, 438 P.2d 867, 871 (1968).

The rule is followed in every state except Maine. See Annot., 54 A.L.R.2d 1298, 1318-19 (1957 \& Supp. 1983). Maine has statutorily provided for a private tort remedy for perjury since the 1800 's. See, e.g., Landers v. Smith, 78 Me. 212, 3 A. 463 (1886); see also ME. Rev. Stat. AnN. tit.14, § 870 (1980).

- See, e.g., Charles v. Wade, 665 F.2d 661, 666 (5th Cir. 1982), cert. denied, 103 S. Ct. 1426 (1983); Nichols v. Alker, 231 F.2d 68, 80 (2d Cir.) (Frank, J., concurring), cert. denied, 352 U.S. 829 (1956).

10 Some observers have noted that a reason that civil actions for perjury have been disfavored is the judicial belief that criminal sanctions provide a sufficient deterrent to false testimony. See Note, supra note 2 , at 350 . Nevertheless, few persons are prosecuted for perjury, and actual imprisonment for a perjury conviction is very rare. Id. at 351; Comment, Perjury: The Forgotten Offense, 65 J. CRIM. L. \& CRIMINologY 361, 361 (1974). Given the pernicious effects of perjury on the justice system, see supra note 2 , the question becomes why there is such limited enforcement of the criminal perjury laws. Commentators have stressed as explanation the obstacles presented by stringent traditional evidentiary rules, see Gershman, supra note 2, at 624 n.4; Comment, supra, at 364 , the difficulty in proving the materiality of the false statement, $i d$. at 365 , or the problems associated with proving the requisite mental state, see Campion \& Hamilton, A Review of Perjury, Litigation, Spring, 1980, at 22. See generally McClintock, What Happens to Perjurers, 24 MINN. L. REv. 727 (1940). Congress has responded to some of these concerns by easing the kinds of proof necessary for a perjury conviction under federal law. See 18 U.S.C. $§ 1623$ (1976 \& Supp. V 1981); Gershman, supra note 2 , at 627 n.10.

${ }_{11}$ Cf. Restatement (FIRST) of Torts $\S 588$ (1938) (emphasis added):

A witness is absolutely privileged to publish false and defamatory matter of another in communications preliminary to a proposed judicial proceeding and as a part of a judicial proceeding in which he is testifying, if it has some relation thereto.

Comment:

$a$. The function of witnesses is of fundamental importance in the administration of justice. The final judgment of the tribunal must be based upon the facts as shown by their testimony, and it is necessary therefore that a full disclosure be not hampered by fear of private suits for defamation. The compulsory attendance of all witnesses in judicial proceedings makes the protection thus accorded the more necessary. The witness is subject to the control of the trial judge in the exercise of the privilege. For abuse of it, he may be subject to criminal prosecution for perjury and to punishment for contempt.

Those concerns weigh less heavily in the context of an investigation by an administrative agency. See infra notes 61-92 and accompanying text. 
ments. ${ }^{12}$ As the Supreme Court announced over a century ago:

There are no maxims of the law more firmly established, or of more value in the administration of justice, than the two which are designed to prevent repeated litigation between the same parties in regard to the same subject of controversy; namely, [the general welfare requires an end to litigation] and [let no man be twice troubled for the same cause]. ${ }^{13}$

The rule reflects this policy of finality at a general level in that if a losing party could maintain an action for perjury, every losing party would be tempted to bring such an action; it is rare that a victorious party speaks the "truth" to the loser's satisfaction. Then the loser of that second proceeding could bring an action for perjury, and so on ad infinitum.

More specifically, the goal of finality of judgments is expressed through the doctrines of res judicata and collateral estoppel. The Supreme Court has defined those two related doctrines in the following way:

Under res judicata, a final judgment on the merits of an action precludes the parties or their privies from relitigating issues that were or could have been raised in that action. Under collateral estoppel, once a court has decided an issue of fact or law necessary to its judgment, that decision may preclude relitigation of the issue in a suit on a different cause of action involving a party to the first case. ${ }^{14}$

In the earliest American case dealing with the rule against civil actions for perjury, Smith $v$. Lewis, ${ }^{16}$ the plaintiff brought an action in a New York court alleging that the defendant had suborned a witness in an earlier trial in Connecticut. The plaintiff claimed that because of the perjured testimony he had been found guilty of land fraud in the prior suit. ${ }^{16}$ The defendant, however, argued that:

This suit is certainly an attempt to overhale [sic] the judgment ... . Such an action is against the settled principles and policy of the law. If maintainable, there will be no end

12 See United States v. Throckmorton, 98 U.S. 61, 65 (1878).

13 Id. The Court's words were: "interest rei publicae, ut sit finis litium" and "nemo debet bis vexari pro una et eadam causa."

14 Allen v. McCurry, 449 U.S. 90, 94 (1980) (citations omitted).

163 Johns. 157 (N.Y. Sup. Ct. 1808).

10 Id. at 158-59. 
to litigation. It will again be trying the same cause . . . . The verdict can never be inquired into, in this way, by a collateral suit. The judgment of the court must be considered as final and conclusive. Res judicata pro veritate accipitur. ${ }^{12}$

The court accepted that reasoning in holding for the defendant. Not to adopt the rule against civil actions, observed Ghief Judge Kent, "would be productive of endless litigation . . . [as it would] allow the losing party to try the cause over again in a counter suit, because he was not prepared to meet his adversary at the trial of the first suit."18

The relationship between the rule and the policy of finality is also illustrated by the one recognized exception to the rule against civil actions for perjury. An action may in fact lie where the alleged perjury is "but an incident" of a larger fraudulent scheme. ${ }^{19}$ In Newin Corp. $v$. Hartford Accident $\mathcal{E}^{\circ}$ Indemnity Co. ${ }^{20}$ the court noted that the rule against civil actions for perjury is based upon the policy that to permit a judgment to be later challenged because it was allegedly tainted with perjury "would be productive of endless litigation." this rule, however,

is based upon the principle that a fraudulent scheme which is greater in scope than the issues that were determined in the action or proceeding may become the basis of an action. This is so, although some of the issues had been determined adversely to the plaintiff in a prior action or proceeding to which, normally, the doctrine of res judicata would apply. ${ }^{22}$

In such a case, the policy of finality of judgments underlying the rule does not apply since the second action is based on an issue-namely, the existence of a fraudulent scheme-broader than that decided in the first action. Since collateral estoppel does not apply to issues yet to be litigated, ${ }^{23}$ we would expect the common law to have developed this exception.

Thus courts, using the language of res judicata and collateral es-

17 Id. at 163 ("a thing adjudged is taken as true").

18 Id. at 168 (Kent, C.J., concurring).

10 Newin Corp. v. Hartford Accident \& Indemnity Co., 37 N.Y.2d 211, 218, 333 N.E.2d 163, 166, 371 N.Y.S.2d 884, 890 (1975); see also Burbrooke Mfg. Co. v. St. George Textile Corp., 283 A.D. 640, 643-44, 129 N.Y.S.2d 588, 589 (1954).

${ }_{20} 37$ N.Y.2d 211, 333 N.E.2d 163, 371 N.Y.S.2d 884 (1975). 168).

21 Id. at 218,333 N.E.2d at 166,371 N.Y.S.2d at 889 (quoting Sinith, 3 Johns. at

22 Newin, 37 N.Y.2d at 217,333 N.E.2d at 167,371 N.Y.S.2d at 889 (quoting Burbrooke Mfg. Co. v. St. George Textile Corp., 283 A.D. 640, 641-44, 129 N.Y.S.2d 588, 589 (1954)).

ss See infra notes 77-81 and accompanying text. 
toppel, ${ }^{24}$ have grounded the rule against civil actions for perjury in concerns reflecting the underlying policy of finality of judgments rather than in policy proscriptions against a new cause of action in tort. ${ }^{28}$ The doctrines representing the policy of the finality of judgments apply most clearly to issues that were or should have been explicitly litigated, as well as to procedural or jurisdictional issues that are often simply implicitly decided by a court in reaching its final decision. ${ }^{26}$ Such issues may only be attacked through a direct challenge to the judgment. ${ }^{27}$

Similarly, if the trier of fact relied on a witness's testimony in reaching its decision, then it necessarily determined the essential issue of fact that the witness did not commit perjury. When insufficient evidence to the contrary is introduced by the opposing party at trial or on direct attack, the issue whether a party has misrepresented facts is finally adjudicated.

The policy of finality is not a harsh or unreasonable principle when applied to court proceedings, because the procedural safeguards associated with trials generally ensure that perjury, if it occurs, will be discovered and brought to the court's attention. ${ }^{28}$ Its application in the context of a particular administrative investigation is addressed in the following section.

24 E.g., Newin, 37 N.Y.2d at 217,333 N.E.2d at 167,371 N.Y.S.2d at 889 ; Smith, 3 Johns. 157; Kanta v. Kessler, 132 N.J.L. 336, 337, 40 A.2d 607, 608 (N.J. 1945).

${ }_{25}$ It is a sovereign state's prerogative to determine what constitutes a cause of action cognizable in its courts. For example, while under California law a plaintiff may recover damages for emotional harm he suffered as a result of watching his child killed or injured because of the defendant's negligence, see Justus v. Atchison, 19 Cal. 3d 564, 139 Cal. Rptr. 97, 565 P.2d 122 (1977); Dillon v. Legg, 68 Cal. 2d 728, 69 Cal. Rptr. 72 (1968); see generally Leibson, Recovery of Damages for Emotional Distress Caused by Physical Injury to Another, 15 J. FAM. L. 163 (1977), such a cause of action is not recognized in New York, see Tobin v. Grossman, 24 N.Y.2d 609, 249 N.E.2d 419, 301 N.Y.S.2d 554 (1969); see generally Simons, Psychic Injury and the Bystander: The Transcontinental Dispute Between California and New York, 51 ST. JoHN's L. REv. 1 (1976). The state weighs broad public policy considerations in deciding whether liability should arise from general social interactions. For example, the New York Court of Appeals has observed that the factors most often considered in deciding whether to recognize a cause of action include the "foreseeability of the injury, proliferation of claims, ... unlimited liability, unduly burdensome liability, and the difficulty of circumscribing the area of liability." Tobin v. Grossman, 24 N.Y.2d at 615, 249 N.E.2d at 422,301 N.Y.S.2d at 558.

The rule against civil actions for perjury, however, focuses exclusively on conduct in a prior judicial proceeding; the courts uphold the rule so as not to allow a new cause of action to spring from prior judicial proceedings.

${ }^{28}$ See Baldwin v. Iowa State Traveling Men's Ass'n, 283 U.S. 522 (1931).

27 E.g., id. (judgment of personal jurisdiction over the defendant held to be res judicata); MCCORMICK's HANDBOOK OF THE LAW OF EvideNCE $§ 52$ (2d ed. 1972 \& Supp. 1978) (consequences of failure to object to admissibility of evidence).

is See 5 J. WIGMORE, EvidenCE $§ 1367$ (J. Chadbourn rev. ed. 1974); infra text following note 64 ; note 70 and accompanying text. 


\section{Application of the Rule to Administrative AGENCY INVESTIGATIONS: Alberta Gas Chemicals, Ltd. v. Celanese Corp.}

The Supreme Court recently denied a petition for certiorari in $\mathrm{Al}$ berta Gas Chemicals, Ltd. v. Celanese Corp. ${ }^{29}$ thereby leaving intact a holding of the United States Court of Appeals for the Second Circuit expanding the rule against civil actions for perjury beyond the adjudicative context to an administrative agency investigation lacking the procedural safeguards found in trials.

The events leading to the Second Gircuit's final disposition of the Alberta Gas case are procedurally complex. To determine whether imports of methanol ${ }^{30}$ priced at less than fair market value were likely to injure the American methanol industry, ${ }^{31}$ the International Trade Commission ("ITC" or "Commission") held hearings on May 15 and 16, 1979. Among those testifying at the hearings were two employees of Celanese Corp., the largest American producer of methanol..$^{32}$ The ITC determined that sales of the imported methanol were not presently injuring the domestic methanol industry but were likely to injure it in the future. ${ }^{3 s}$ That determination, obligating the Treasury Department to issue a Finding of Dumping, ${ }^{34}$ resulted in the imposition of antidumping duties on imports of Canadian methanol. ${ }^{35}$

Alberta Gas Chemicals, Ltd. ("Alberta Gas"), the largest Canadian producer of methanol, ${ }^{36}$ filed an action in the United States Court of International Trade shortly after the imposition of those duties. ${ }^{37}$

29 497 F. Supp. 637 (S.D.N.Y. 1980), rev'd, 650 F.2d 9 (2d Cir.), on remand, 529 F. Supp. 226 (S.D.N.Y. 1981), affd mern., 697 F.2d 287 (2d Cir.) (unpublished decision), cert. denied, 103 S. Ct. 580 (1982).

${ }^{30}$ Methanol is an important organic chemical used as a general solvent and as a basic building block in producing many other chemicals.

I1 The Commission acted pursuant to $\S 201(a)$ of the Antidumping Act of 1921. 19 U.S.C. §§ 160-171 (1976), repealed by Pub. L. No. 96-39, Title I, § 106(a), 93 Stat. 193 (1979). The present Antidumping Act is found at 19 U.S.C. $\S \S 1673-1677$ (Supp. V 1981).

32 The hearings are reported at 44 Fed. Reg. 40,734 (July 12, 1979). For a description of the procedures used at the hearings see infra notes 64-68 and accompanying text; note 71 .

ss See 44 Fed. Reg. 40,734 (July 12, 1979). 1981)).

st See 19 U.S.C. $§ 160$ (a) (1976) (present version at 19 U.S.C. $§ 1673$ (Supp. V

${ }_{35}$ See 44 Fed. Reg. 44,154 (July 27, 1979).

so Alberta Gas Chems. Ltd. v. Celanese Corp., 497 F. Supp. at 638.

37 The action was actually filed in the United States Customs Court pursuant to 28 U.S.C. § 1582 (1976), amended by Pub. L. No. 96-417, tit. II, § 201, 94 Stat. 1729 (codified at 28 U.S.G. $\S 1581$ (Supp. V 1981)). During the course of the litigation, however, the Customs Court was renamed the United States Court of International Trade. See 28 U.S.C. 1581 (Supp. V 1981). See generally 22 HaRV. INT'L L.J. 480 
Seeking reversal of the Commission's determination, Alberta Gas alleged that the decision was not supported by the testimony received at the hearing. ${ }^{38}$

On April 2, 1980, while the action in the international trade court was still pending, Alberta Gas filed a diversity action against Celanese Corp. in federal district court. ${ }^{30}$ The complaint claimed that Celanese engaged in a pattern of unfair competition by intentionally giving false testimony to the Commission ${ }^{\mathbf{0}}$ when it underrepresented the projected demand for methanol in the United States in the 1980's. ${ }^{41}$ Alberta Gas also alleged that Celanese intentionally concealed from the Commission its plans to build'a $\$ 255$ million facility in Canada; the output of which was to be exported to the United States. ${ }^{42}$ Alberta Gas further alleged that Celanese deliberately failed to disclose to the Commission its plans to construct in the United States "the world's largest methanol producing facility." Is If the Commission had known of those plans, then it presumably would have disbelieved Celanese's low demand estimates, and it would have been less likely to find a probability of future injury

(1981). To avoid unnecessary confusion, this Comment refers to the court as the Court of International Trade.

38 Alberta Gas Chems., Ltd. v. United States, 515 F. Supp. 780, 783-84 (Ct. Int'l Trade 1981). Alberta Gas apparently did not then know of the alleged perjured testimony before the Commission. In any event, the Court of International Trade does not have the power to award damages as compensation for such perjury. 28 U.S.C. $\S 1581$ (1976), deleted by Pub. L. No. 96-417, tit. II, § 201, 94 Stat. 1728 (codified at 28 U:S.C. $\$ 1581$ (Supp. V 1981)). The powers of the court are now found at 28 U.S.C. $\S$ 1585 (Supp. V 1981). 1980).

30 Alberta Gas Chems., Ltd. v. Celanese Corp., 497 F. Supp. 637 (S.D.N.Y.

40 Complaint, If 8, Alberta Gas Chems., Ltd. v. Celanese Corp., 497 F. Supp. 637 (S.D.N.Y. 1980). Two Celanese employees testified at the ITC hearings. See 44 Fed. Reg. 40,734 (July 12, 1979). In their testimony before the Commission, they allegedly falsified and failed to disclose material facts. See infra text accompanying notes 41-43.

If Celanese had not intentionally misled the Commission, any damages suffered by Alberta Gas would have been non-actionable, the result of legitimate governmental action by the Commission. Cf. Woods Exploration \& Prod. Co. v. Aluminum Co. of Am., 438 F.2d 1286, 1293-95 (5th Cir. 1971), cert. denied, 404 U.S. 1047 (1972), discussed infra note 92 .

4 Complaint, II 10, Alberta Gas.

An important factor used by the Commission to decide whether imports were likely to damage the American industry was the expected future demand for methanol in the United States. If demand grew rapidly, future imports would not hurt the sales of domestic manufacturers; conversely, if demand stagnated or declined, future imports would be more likely to injure the industry.

42 Complaint, I 9, Alberta Gas. It was during Celanese's effort to secure permission from the Canadian government for construction of its new plant that it disclosed that, contrary to its earlier testimony before the ITC, the demand for methanol during the 1980's in the United States would far exceed supply. See Petition for Writ of Certiorari at 4, Alberta Gas, 697 F.2d 287 (2d Cir.), cert. denied, 103 S. Ct. 580 (1982).

4s Complaint, If 9, Alberta Gas. 
to the United States methanol industry. ${ }^{44}$

Alberta Gas alleged that it had sustained damages because it had to delay the construction of additional methanol production facilities in Canada and because its reputation as a reliable supplier had been damaged by the Commission's determination. ${ }^{45}$ Those damages, Alberta Gas claimed, had been foreseen by Celanese and intentionally brought about to directly benefit that company as a competitor of Alberta Gas. ${ }^{48}$

The district court dismissed the complaint for failure to state a claim upon which relief could be granted, citing the rule against actions for perjury. ${ }^{47}$ On appeal, the Second Circuit reversed and remanded, stating that the doctrine of primary jurisdiction ${ }^{48}$ required the district court to stay its proceedings until the Commission was given the opportunity to decide whether its determination had been based on Celanese's testimony. ${ }^{49}$ That question, if answered affirmatively, would have constituted the element of causation necessary to maintain an action in tort. ${ }^{\text {so }}$

44 Id. $\Uparrow 11$.

15 Id. II 12 \& 15.

16 See id. $\pi 8$.

${ }^{17}$ Alberta Gas, 497 F. Supp. at 639-40. The court dismissed the complaint pursuant to FED. R. Grv. P. 12(b)(6). Under Rule 12(b)(6), courts must accept the facts alleged in a complaint as true. See Walker Process Equipment, Inc. v. Food Machinery and Chem. Corp., 382 U.S. 172, 175 (1965); see also 2A J. MOORE \& J. LuCAs, Moore's Federal Practice II 12.08 (2d ed. 1983).

${ }_{18}$ The doctrine of primary jurisdiction holds that where an issue in a case before a court is within the special jurisdiction and power of an administrative agency, the court should stay its proceedings in order to let the agency decide the issue. See United States v. Western Pac. R.R., 352 U.S. 59, $63-65$ (1956). See generally Convisser, Primary Jurisdiction: The Rule and Its Rationalizations, 65 YALE L.J. 315 (1956); Note, Administrative Law-Primary Jurisdiction: The Misuse of Primary Jurisdiction Retroactively to Extinguish a Tort Remedy: Nader v. Allegheny Airlines, Inc., 512 F.2d 527 (D.C. Cir. 1975), 8 ConN. L. REv. 584 (1976); Note, Administrative Law-Primary Jurisdiction-A Judicial Tool To Force Regulatory Agencies to Formulate Clear-Cut Policies, 10 MEM. ST. U.L. REv. 774 (1980).

${ }^{10}$ Alberta Gas Chems., Ltd. v. Celanese Corp., 650 F.2d at 12-14.

so Id. at 12. The court earlier stated: "It is quite clear to us that Alberta is trying to obtain a reversal of the Commission's ruling without bothering to attempt to utilize other remedies available to it, and we see no reason to countenance such use of the federal courts." Id. Yet Alberta Gas was not trying to obtain a reversal of the Commission in federal court, as became more evident when it continued pressing its suit for damages even after the Court of International Trade vacated the Commission's findings. See infra text accompanying and following notes 51-54. Alberta Gas had no "other remedies available to it." For instance, the Commission lacks authority to hear any dispute a party should bring before it, see 19 U.S.C. $\$ \S 160-171$ (1976), nor does a procedure exist by which the Commission can reopen a concluded hearing.

The Second Circuit nevertheless noted that all administrative agencies have the "inherent" power to do whatever is reasonably necessary to prevent themselves from being defrauded, irrespective of statutory authority. 650 F.2d at 12-13. After the Second Circuit remanded the case to the district court, Alberta Gas applied to the Commission for a determination whether Celanese had misrepresented facts to the ITC and, 
Two weeks later, the Court of International Trade, presumably without any knowledge of the alleged misrepresentations, ${ }^{51}$ reversed the Commission by holding that there was not enough evidence for the Commission to find a likelihood of future injury to the domestic methanol industry. ${ }^{52}$ That decision, however, merely removed the special antidumping duties; it did not compensate Alberta Gas for the millions of dollars in business damages that it had allegedly suffered in the interim. ss $^{\text {ss }}$

After the Commission had subsequently refused to determine whether its now vacated determination concerning methanol imports had been based on Celanese's testimony, ${ }^{\text {b4 }}$ Alberta Gas returned to the district court, which dismissed the complaint again, incorporating by reference its original decision..$^{\text {s5 }}$ In an unpublished decision, the Second Circuit affirmed without an opinion. ${ }^{58}$ The United States Supreme

if so, whether those misrepresentations had resulted in the ITC's finding of likely future injury to the domestic methanol industry. On August 26, 1981 the Commission, however, denied the request stating, inter alia, that it lacked procedures to hear the issues. Brief of Plaintiff-Appellant at 3, Alberta Gas Chems., Ltd. v. Celanese Corp., 697 F.2d 287 (2d Cir. 1982).

s1 The alleged misrepresentations and frauds were neither pleaded in the complaint nor mentioned by the court in its opinion. See Alberta Gas Chems., Ltd. v. United States, 515 F. Supp. 780 (Ct. Int'l Trade 1981).

82 Id.

ss Again, it should be kept in mind that the damages that Alberta Gas was seeking to recover, see supra text accompanying note 45 , remained even after the Court of International Trade reversed the Commission. See Petition for Writ of Certiorari at 5 n.4, Alberta Gas, 697 F.2d 287 (2d Cir.), cert. denied, 103 S. Ct. 580 (1982).

of See supra note 50 . The Commission reasoned that the reversal of its determination adverse to Alberta Gas had corrected the alleged injuries suffered. See Petition for Writ of Certiorari at app. H, Alberta Gas, 697 F.2d 287 (2d Cir.), cert. denied, 103 S. Ct. 580 (1982). The Commission also held that it lacked authority to determine whether Celanese had committed perjury, instead referring the charge to the Department of Justice for possible prosecution. Id. 1981).

so Alberta Gas Chems., Ltd. v. Celanese Corp., 529 F. Supp. 226, 227 (S.D.N.Y.

Be Alberta Gas Chems., Ltd. v. Celanese Corp., 697 F.2d 287 (2d Cir.) cert. denied, 103 S. Ct. 580 (1982). Under the Second Circuit's Rule 0.23, unreported opinions are not precedent and may not be cited by or to the courts of that circuit. See 2D CIR. R. 0.23. For commentary on unpublished opinions in the federal courts, see, e.g., Reynolds \& Richman, The Non-Precedential Precedent-Limited Publication and NoCitation Rules in the United States Courts of Appeals, 78 Colum. L. REv. 1167 (1978); Stern, The Enigma of Unpublished Opinions, 64 A.B.A. J. 1245 (1978); Note, Unreported Decisions in the United States Courts of Appeals, 63 CoRNELL L. Rev. 128 (1977). For evaluations of the success of the federal circuits' limited publication rules, see, e.g., Hoffman, Nonpublication of Federal Appellate Court Opinions, 6 Just. Sys. J. 405 (1981); Reynolds \& Richman, Limited Publication in the Fourth and Sixth Circuits, 1979 Duke L.J. 807 (1979); Reynolds \& Richman, An Evaluation of Limited Publication in the United States Courts of Appeals: The Price of Reform, 48 U. CHI. L. REv. 573 (1981); Shuchman \& Gelfand, The Use of Local Rule 21 in the Fifth Circuit: Can Judges Select Cases of "No Precedential Value"?, 29 EMoRY L.J. 195 (1980); Comment, A Snake in the Path of the Law: The Seventh Circuit's Non- 
Court eventually denied Alberta Gas's petition for certiorari. ${ }^{57}$

In its original decision the district court seemed to view the Alberta Gas suit as a collateral attack on the judgment of the ITC.88 After the Court of International Trade reversed the Commission's findings, however, no ITG judgment remained for Alberta Gas to attack in any manner. It should have been clear that by filing suit against Gelanese, Alberta Gas, rather than collaterally attacking the ITC determination which had already been vacated, was seeking compensation for damages suffered-damages that were not affected by the reversal of the Commission's decision. . $^{50}$

Neither court discussed the appropriateness of applying a rule developed for judicial proceedings to the investigation conducted by the ITC. ${ }^{60}$ The rule's validity in that investigatory context is examined in the following section.

\section{The Rule Should Not Apply to Administrative Actions Such as ITG Investigative Proceedings}

Federal regulations characterize the ITC proceedings at which Celanese allegedly committed perjury as a nonadjudicative investigation. ${ }^{61}$ Although Congress has given different powers and procedures to each agency, ${ }^{62}$ and each agency is generally able to formulate its own rules and procedures, ${ }^{68}$ certain general observations can be made about

Publication Rule, 39 U. PITT. L. REv. 309 (1977). Although Alberta Gas lacks precedential value, it nevertheless illustrates the problems with incorrectly extending the rule against civil actions for perjury.

${ }^{37}$ Alberta Gas Chems., Ltd. v. Celanese Corp., 103 S. Ct. 580 (1982).

s8 "The sole issue . . . under plaintiff's complaint . . . is whether the Commission's determination was properly reached . . . . As for plaintiff's other claims . . . their obvious purpose is to . . nullify the Commission's determination." 497 F. Supp. at 640 .

so See supra note 50 and accompanying text.

60 The parties to the litigation seem to have restricted their arguments in the district court and court of appeals to the appropriateness of applying the exception to the rule, see supra notes 19-23 and accompanying text, rather than the appropriateness of applying the rule itself to this context. See, e.g., Alberta Gas, 497 F. Supp. at 639-40. If so, the appropriateness of applying the rule against civil actions for perjury to the Commission's investigatory hearings was raised expressly only before the Supreme Court. See Petition for Writ of Certiorari at $i$, Alberta Gas.

o1 When the Commission's investigation was conducted in the Spring of 1979, the applicable regulations were contained in 19 C.F.R. $\$ 207$ (1979), under Subchapter B entitled "Nonadjudicative Investigations."

${ }^{2}$ G. Robinson, E. Gellhorn \& H. Bruff, The Administrative Process 3, 33-34 (2d ed. 1980). Most agencies are subject to the Administrative Procedure Act, 5 U.S.C. $\S \S 551-559,701-706$ (1982), which exerts a homogenizing pressure. But see infra notes 65-68; note 71 and accompanying text.

os See G. Edles \& J. Nelson, Federal Regulatory Process: Agency Practices \& Procedures $\$ \S 2.1,6.6$, at 29, 112.1 (1981). 
the substantial differences between investigations by administrative agencies and judicial or administrative adjudications.

First, in no investigation does a "party" 64 have as ample an opportunity to cross-examine another "party" as he would have in a court. ${ }^{65}$ Certainly Alberta Gas, for example, had little opportunity for crossexamination at the ITC hearing. While under the ITC's enabling statute at the time of the hearing ${ }^{66}$ the Commission could allow Alberta Gas to intervene at the hearing and to present its testimony, ${ }^{67}$ the Commission severely limited the opportunity to cross-examine witnesses. ${ }^{68}$ Yet, cross-examination is crucial to uncovering any fraud or mișrepresentation in the testimony before the Commission. Wigmore called cross-examination "beyond any doubt the greatest legal engine ever in-

64 The term "party" has a different meaning in the context of an investigation by an administrative agency than it does in the context of a judicial proceeding. In the ITC's methanol hearings, for example, not all interested parties needed to be joined. See infra note 67 and accompanying text. The Commission merely published an announcement in the Federal Register that it would be holding the methanol hearings and that interested parties could participate. See 44 Fed. Reg. 19,090 (March 30, 1979).

${ }_{65}$ In addition to direct limits placed on cross-examination in an agency proceeding, see, e.g., infra note 68 , a party's ability to conduct meaningful cross-examination is also limited by the inability to engage in full discovery, see infra notes 71-74 and accompanying text.

${ }_{68}$ The Antidumping Act of 1921 as amended, 19 U.S.C. $\$ \S 160-171$ (1976) (repealed 1980).

or Before making any determination ... . the Commission . . . shall, at the request of [domestic manufacturers or importers] of the [product] in question, conduct a hearing at which-

(A) any such person shall have the right to appear by counsel or in person; and

(B) any [interested person] upon good cause shown, may be allowed by . . . the Commission . . . to intervene and appear at such hearing by counsel or in person.

19 U.S.C. $\S 160(d)(1)(1976)$. follows:

os The hearings were subject to 19 C.F.R. $\S 201.12$ (1979) which provides as

(c) Questioning of witnesses.

After completing testimony, a witness may be questioned by any member of the Commission or by its staff. Any person who has entered an appearance ... may, with the permission of the presiding officials, direct questions to the witness, but only for the purpose of assisting the Commission in obtaining relevant and material facts with respect to the subject matter of the investigation.

The applicable regulations, 19 C.F.R. $\S 207.4$ (c)(3) (1979), also noted that the ITC was exempt from several provisions of the Administrative Procedure Act, including 5 U.S.C. $\$ \S 554-557,702$ (1976 \& Supp. V 1981). The new statute that governs the ITC, 19 U.S.C. \& 1677c(b) (Supp. V 1981), exempts the agency from many of the same provisions, including 5 U.S.C. $\$$ 556(d) (1976) which provides that: "A party is entitled to present his case or defense by oral or documentary evidence, to submit rebuttal evidence, and to conduct such cross-examination as may be required for a full and true disclosure of the facts." 
vented for the discovery of truth"69 and considered cross-examination, not the jury trial, to be the most significant contribution of AngloAmerican jurisprudence to a workable system of justice. ${ }^{70}$ Without an effective opportunity to cross-examine witnesses, a "party" is at a serious disadvantage in trying to uncover misleading statements or fraud perpetrated during an investigation.

Similarly, effective cross-examination requires adequate discovery procedures. The ITC, however, denied Alberta Gas any right to discovery. ${ }^{71}$ The advent of the liberal pre-trial discovery provisions of the Federal Rules of Givil Procedure ${ }^{72}$ has been widely recognized as a major innovation contributing toward increased equity. ${ }^{73}$ Without discovery, a party will often be powerless to determine whether an adverse party is misrepresenting or omitting material facts in its presentation. As alleged in Alberta Gas, such fraud might only be discovered after the investigation by the agency is completed and a party is injured. ${ }^{74}$

These observations are taken into account by the limited application of the doctrine of res judicata to administrative agency actions. Res judicata applies only when the agency "is acting in a judicial capacity, and resolves disputed issues of fact properly before it which the parties have had an adequate opportunity to litigate."75 Davis observes that in "name and tradition 'res judicata' means thing adjudicated. Only what is adjudicated can be res judicata. Administrative action other than ad-

69 $5 \mathrm{~J}$. WIGMORE, supra note $28, \S 1367$, at 32 .

${ }^{70}$ Id.; cf. Watkins v. Sowders, 449 U.S. 341,349 (1981) ("the time honored process of cross-examination [is] the device best suited to determine the trustworthiness of testimonial evidence"); Ohio v. Roberts, 448 U.S. 56, 78 (1980) (Brennan, J., dissenting) ("There are few subjects, perhaps, upon which this Court and other courts have been more nearly unanimous than in their expressions of belief that the right of confrontation and cross-examination is an essential and fundamental requirement for the kind of fair trial which is this country's constitutional goal." ") (quoting Pointer v. Texas, 380 U.S. 400, 405 (1965)).

71 The regulations governing the methanol hearings as part of a nonadjudicative investigation by the ITC made no provision for discovery by the parties. See 19 C.F.R. $\S \S 201.7-.16 \& 207.1-.6$ (1979). Compare those provisions with 19 C.F.R. $\$ \S 210.30$ .36 (1979) (adjudicative investigations). Cf., 4 B. MEzines, J. Stein, J. Gruff, ADMiNisTRATIVE LAW $\S 23.02$, at 23-42 to 23-45 (1982) (citations omitted) ("As reflected by the [Administrative Procedure Act] and agency statutes and rules, no nonagency party under investigation or otherwise associated with an investigation has rights of discovery.").

73 See Fed. R. Giv. P. 26-37.

73 See Hickman v. Taylor, 329 U.S. 495, 500-01 (1947).

74 See supra text accompanying note 51 . The lack of adequate opportunity to obtain discovery and cross-examine witnesses hinders a party's own search for relevant facts. See supra notes $68 \& 71$ and accompanying text.

75 See United States v. Utah Constr. \& Mining Co., 384 U.S. 394, 422 (1966). See generally 4 K. Davis, Administrative Law Treatise $\$ \S 21: 3,21: 9$ (1983). 
judication cannot be res judicata." 78

Similarly, regarding collateral estoppel, the Supreme Court has required that the party estopped must have had a "fair and full opportunity to litigate" the issue in the prior action. ${ }^{77}$ Hence, parties who never appeared in the prior action clearly "may not be collaterally estopped without litigating the issue. They have never had a chance to present their evidence and arguments on the claim. Due process prohibits estopping them...."?8

Even between the same parties to a prior action, differences in available procedures (for instance, a litigant's ability to engage in full scale discovery or call witnesses) may justify precluding a prior judgment from having estoppel effect in a subsequent action. ${ }^{78}$ The Supreme Court has stated that it might be unfair to apply offensive collateral estoppel when the second action affords the defendant procedural opportunities unavailable in the first action that might readily cause a different result. ${ }^{80}$

If, for example, the defendant in the first action was forced to defend in an inconvenient forum and therefore was unable to engage in full scale discovery or call witnesses, application of offensive collateral estoppel may be unwarranted. Indeed, differences in available procedures may sometimes justify not allowing a prior judgment to have estoppel effect in a subsequent action even between the same parties, or where defensive estoppel is asserted against a plaintiff who has litigated and lost. ${ }^{81}$

As noted above, ${ }^{82}$ the rule against civil actions for perjury is

76 K. Davis, Administrative Law Text $\S 18: 08$, at 368 (3d ed. 1972).

73 Parklane Hosiery Co. v. Shore, 439 U.S. 322, 333 (1979) (quoting BlonderTongue Laboratories, Inc. v. University of Ill. Found., 402 U.S. 313, 333 (1971)).

78 Blonder-Tongue Laboratories, Inc. v. University of Ill. Found., 402 U.S. 313, 329 (1971).

7e See Parklane Hosiery Co. v. Shore, 439 U.S. 322, 330-31 (1979); see also RESTATEMENT (SECOND) OF JUDGMENTS $\$ 29$ comment d (1982):

d. Fuller procedural opportunities in second action. Preclusion may be withheld when the party against whom it is invoked can avail himself of procedures in the second action that were not available to him in the first action and that may have been significantly influential in determination of the issue. Differences in this regard include such procedures as discovery devices and plenary as distinct from summary hearing. It may also be relevant that the party against whom preclusion is invoked had no choice or restricted choice, as to the forum in which the issue was litigated.

80 Parklane Hosiery Co. v. Shore, 439 U.S. 322, 330-31 (1979).

${ }^{81}$ Id. at 331 n.15 (emphasis added).

s2 See supra notes 12-28 and accompanying text. 
closely related to the doctrines and policies of res judicata and collateral estoppel. Significantly, courts have recognized that the rule against civil actions for perjury assumes that the injured party had a fair and full opportunity to present its case in the proceeding where the perjury occurred. For example, the Supreme Court in United States $v$. Throckmorton ${ }^{83}$ justified its application of the rule by observing that the first action had provided the petitioner with "ample time to make all necessary inquiries and produce the necessary proof, if it existed, of the fraud." the class of cases "where by reason of something done by the successful party to a suit, there was in fact no adversary trial or decision of the issue in the case."

The dramatic differences in procedure ${ }^{86}$ afforded Alberta Gas in its suit in federal court, in contrast to the ITC's methanol hearings, ${ }^{82}$ militate against applying the rule to bar that suit. When the rule is applied to a plaintiff seeking redress for perjury committed in a prior judicial proceeding, that plaintiff had an opportunity of uncovering the perjury during that proceeding, or at least an opportunity to bring a direct attack on the judgment. ${ }^{88}$ In a situation such as that in Alberta Gas, however, the plaintiff had no realistic opportunity to discover the alleged misrepresentations until long after the proceedings were concluded. There was no discovery, no chance to cross-examine witnesses, and Alberta Gas "had no choice or restricted choice, as to the forum in which the issue was litigated."

Furthermore, at no time until its suit for perjury was Alberta Gas in a forum where it could recover damages for its injuries. Both the Commission and the Court of International Trade were powerless to provide a remedy since they are without jurisdiction to provide damages in tort. ${ }^{90}$ That contrasts with the situation in which perjury is committed before a court. There the injured party could seek relief during the proceeding or in a direct attack on the judgment. ${ }^{21}$ Thus, the rule's

8398 U.S. 61 (1878).

st Id. at 64 .

8 Id. at 65.

${ }^{80}$ Those differences are justified since they allow an administrative agency to operate more quickly and inexpensively than full judicial procedures would. See generally 1 K. DAvis, supra note 75 , at $\S 6: 39$. The use of streamlined procedures, however, militates against the application of the rule against civil actions for perjury.

87 See supra notes $65 \& 71$ and accompanying text.

ss See supra note 6 and accompanying text.

80 See supra notes 68,71 \& 79 and accompanying text.

- See supra note 37 and accompanying text.

92 See supra note 6 and accompanying text. Relief is limited to restitution rather than damages. 
effects are more harsh in the type of setting present in Alberta Gas-the administrative agency investigation-than in judicial proceedings.

Finally, administrative investigations lacking effective cross-examination, discovery, and other procedural safeguards render government agencies susceptible to intentional misrepresentations. Agencies seeking to lower the cost of conducting an investigation, which could become prohibitively expensive and time consuming were the full panoply of discovery and cross-examination procedures made available to every party, risk the possibility that parties will defraud them. The risk of fraud, however, can be minimized by allowing injured parties to enforce the rules against perjury through private suits. ${ }^{92}$

92 Under federal antitrust laws, courts have permitted plaintiffs to maintain causes of action for damages caused by alleged misrepresentations madé to administrative agencies. In Clipper Exxpress v. Rocky Mountain Motor Tariff Bureau, Inc., 674 F.2d 1252 (9th Cir. 1982), cert. denied, 103 S. Ct. 1234 (1983), the plaintiff, a freight forwarder, sued certain competitors and a trucking rate bureau alleging that the defendants had made misrepresentations to the Interstate Commerce Commission in connection with plaintiff's application to that agency for a rate reduction. Although the plaintiff eventually obtained the reduction, it was damaged by the delay, id. at 1272 , just as Alberta Gas had claimed to be. See supra notes $45 \& 53$ and accompanying text. The Ninth Circuit allowed a cause of action for damages under the antitrust laws, although it didn't discuss the rule against actions for perjury.

The facts of Clipper Exxpress are strikingly similar to those in Alberta Gas. In both cases, the plaintiffs alleged they had been damaged by intentional misrepresentations made during agency investigations. In both cases, the determination of the agency, while originally unfavorable to the plaintiff, later was reversed; yet damages remained. See supra text accompanying notes 58-59. Although the former was brought under federal antitrust laws while the latter was brought under a state common law doctrine of unfair competition, that is a distinction without a difference since the policy concerns that caused the courts in Alberta Gas to invoke the rule against civil actions for perjury, see supra notes 12 \& 47 and accompanying text, were also present in Clipper Exxpress. Furthermore, there is no evidence that Congress impliedly repealed the rule by enacting the antitrust laws. Nevertheless, the Ninth Circuit did not apply the rule.

Clipper Exxpress relied on Israel v. Baxter Laboratories, Inc., 466 F.2d 272 (D.C. Cir. 1972), and Woods Exploration \& Producing Co. v. Aluminum Co. of Am., 438 F.2d 1286 (5th Cir. 1972), cert. denied, 404 U.S. 1047 (1972). In Israel, the plaintiff alleged that the defendant had made misrepresentations to the Food and Drug Administration about the nature of a drug manufactured by the plaintiff. Those misrepresentations led the FDA to keep the drug, which was similar to a product manufactured by the defendant, off the market. The action was based on both federal and state antitrust laws. The circuit court did not discuss the rule against civil actions for perjury, but held that the complaint stated a valid cause of action under the antitrust laws.

In Woods, the plaintiff alleged that the defendant conspired to commit perjury before the Texas Railroad Commission in order to persuade the Commission to reduce the amount of gas the plaintiff would be allowed to pump from a field shared with the defendant. The Fifth Circuit held that where an agency is given false facts upon which it must rely, an antitrust action may be maintained against the private defrauder. 438 F.2d at 1296.

The alleged misrepresentations in Clipper Exxpress do not fit the definition of "perjury" under federal criminal law, 18 U.S.C. \& 1623 (1976 \& Supp. V 1981), but may still be punishable under the federal statute which makes it a crime to knowingly 


\section{ConClusion}

The rule against civil actions for perjury is grounded in the policy of the finality of judgments, and the doctrines of res judicata and collateral estoppel. In deciding whether to apply the rule, the best guide is the established body of precedents regulating the application of those related doctrines. The justification for the use of those doctrines diminishes as the opportunity for a full and fair determination of the facts in question wanes. Similarly, the applicability of the rule should be questioned as the procedures involved in a given context shift from the full procedural safeguards of judicial proceedings to the streamlined administrative agency investigatory setting. The ITG investigative hearing involved in Alberta Gas Chemicals, Ltd. $v$. Celanese Corp. ${ }^{93}$ lacked provision for discovery and cross-examination, two of the most important procedural safeguards for rooting out fraud. The Second Circuit's sanctioning of the application of the rule ignored these vital differences.

and wilfully conceal or misrepresent material facts before any department or agency of the United States. See 18 U.S.C. § 1001 (1976 \& Supp. V 1981). The rationale for the recognition of a civil action for such misrepresentations despite the existence of a criminal penalty, and despite the possibility that the civil action will call into question a "final" agency determination, is noteworthy. As the ICC explained in its amicus brief in Clipper Exxpress, many government agencies, because of their scarce staff resources, must rely on the parties to an issue to tell the truth. A misrepresentation may thus go undetected by the agency unless another party becomes aware of the wrongdoing and reports it. 674 F.2d at $1272 \mathrm{n} .34$. Such detection during an agency proceeding may only be likely when the parties are afforded the procedural tools to make that discovery. See supra notes $74 \& 89$ and accompanying text. The recognition of a civil action for such misrepresentations provides added incentive for a party to bring the wrongdoing to light, Clipper Exxpress, 674 F.2d at 1272 n.34, and may "be sufficient to induce parties not to misrepresent facts." Id. at 1271.

's Alberta Gas Chems., Ltd. v. Celanese Corp., 497 F. Supp. 637 (S.D.N.Y.), rev'd, 650 F.2d 9 (2d Cir. 1980), on remand, 529 F. Supp. 226 (S.D.N.Y.), affd mem., 697 F.2d 287 (2d Cir. 1981) (unpublished decision), cert. denied, 103 S. Ct. 580 (1982). 


\section{.}

